\title{
Additional Ancestral Caddo Ceramic and Lithic Artifacts from the Three Mounds Creek Site, Gregg County, Texas
}

Timothy K. Perttula

Heritage Research Center, Stephen F. Austin State University

Follow this and additional works at: https://scholarworks.sfasu.edu/ita

Part of the American Material Culture Commons, Archaeological Anthropology Commons, Environmental Studies Commons, Other American Studies Commons, Other Arts and Humanities Commons, Other History of Art, Architecture, and Archaeology Commons, and the United States History Commons

Tell us how this article helped you.

This Article is brought to you for free and open access by the Center for Regional Heritage Research at SFA ScholarWorks. It has been accepted for inclusion in Index of Texas Archaeology: Open Access Gray Literature from the Lone Star State by an authorized editor of SFA ScholarWorks. For more information, please contact cdsscholarworks@sfasu.edu. 
Additional Ancestral Caddo Ceramic and Lithic Artifacts from the Three Mounds Creek Site, Gregg County, Texas

\section{Creative Commons License}

\section{(c) (1) (8)}

This work is licensed under a Creative Commons Attribution-NonCommercial 4.0 International License 


\title{
Additional Ancestral Caddo Ceramic and Lithic Artifacts from the Three Mounds Creek Site, Gregg County, Texas
}

\author{
Timothy K. Perttula
}

\section{INTRODUCTION}

The Three Mounds Creek site is an ancestral Caddo multiple mound center along a southern-flowing tributary to the Sabine River in the Longview, Texas area. Buddy Jones recorded the site in 1956, and noted that it had three mounds. His notes fail to describe the mounds in any fashion, nor their relationship to each other or the landform they were built on, and no map is available that shows the location of the three mounds with respect to where he collccted artifacts from the site.

In April 1956, Jones excavated a $9.5 \times 12 \mathrm{ft} .(2.9 \times 3.6 \mathrm{~m})$ unit at the site, in an old cotton field. It is unknown if this unit was placed in one of the three mounds, or what the vertical, horizontal, or depositional context of the artifacts was from the site. Perttula (2012) described a collection of 264 artifacts from that work that are in the Gregg County Historical Museum (GCHM), and these were primarily ceramic sherds $(n=242,92 \%)$. Two additional collections from the site (accession nos. 2003.08.3123 and 2003.08.3124) were subsequently identified in the GCHM, and these were analyzed in January 2013. The results of those analyses are presented in this article.

\section{ARTIFACT COLLECTIONS}

The remaining two GCHM collections from the Three Mounds Creek site include 10 dart points, two arrow point fragments, and 247 ceramic sherds. Together with the animal bone and mussel shell fragments described by Perttula (2012:Table 1), as well as lithic debris, and the abundance of ceramic sherds, this suggests that Jones' excavation may have been placed in a domestic habitation area at the site.

\section{Ceramic Sherds}

The additional ceramic sherds include 211 plain rim, body, and base sherds, and 36 decorated sherds. Approximately $78 \%$ of the sherds are from grog-tempered vessels, and the remainder are from vessels tempered with burned bone (Table 1).

The 35 decorated sherds from Caddo vessels are primarily from utility ware jars ( $n=33,94 \%$ ), with only two fine warc sherds $(n=2,6 \%)$. Many of the utility ware sherds are body sherds with brushing marks (see Table 1). Utility ware rims include: horizontal brushed ( $n=1$, everted rim jar); closely-spaced horizontal incised lines ( $n=1$, bowl with a rounded and exterior folded lip); diagonal incised lines ( $n=1$, everted rim jar with a $22 \mathrm{~cm}$ orifice diameter); and an everted rim jar sherd with tool punctate-filled incised triangles. Brushed sherds comprise $49 \%$ of the decorated sherd assemblage in the two collections. One lower rim-body sherd has diagonal incised lines on the rim that are pitched from right to left, a row of linear tool punctations at the rim-body juncture, and diagonal incised lines on the body that are pitched from the left to right. A body sherd has a curvilinear incised zone filled with circular tool punctations.

Both fine ware sherds are from bottles with engraved lines. One sherd has horizontal lines with large pendant triangles whose apexes point towards each other. A similar sherd was identified in the first collcction analyzed by Perttula (2012:35). This engraved decorative element on bottles is one of the consistently 
occurring elements in a Middle Caddo period (ca. A.D. 1200-1450) style zone that has been recognized in Caddo communities in the Angelina, Sabine, and Big Cypress stream basins (Hart and Perttula 2010:203-207).

Table 1. Ceramic sherds from additional collections at the Three Mounds Creek site.

\begin{tabular}{lccc}
\hline Sherd type & Grog-tempered & Bone-tempered & N \\
\hline plain rim & 7 & 1 & 8 \\
plain body & 144 & 37 & 181 \\
plain base & 17 & 5 & 22 \\
& & 7 & 17 \\
brushed & 10 & 2 & 8 \\
incised & 6 & 2 & 5 \\
incised-punctated & 3 & - & 3 \\
punctated & 3 & 1 & 2 \\
engraved & 1 & - & 1 \\
dentate stamped & 1 & 55 & 247 \\
\hline Totals & 192 & & \\
\hline
\end{tabular}

Together, all three collections from the Three Mounds Creek site at the GCHM have 66 decorated sherds (Table 2). Utility wares account for $95.5 \%$ of the assemblage. with very few fine wares. Brushed and brushed-incised sherds comprise $56 \%$ of the utility wares, and $53 \%$ of all the decorated sherds, with the remainder of the utility ware sherds from jars decorated with incised, punctated, and incised-punctated elements. The few engraved fine wares are only from bottles.

Table 2. Summary of the decorated Caddo sherds from the Three Mounds Creek site in the Buddy Jones Collection.

\begin{tabular}{lcc}
\cline { 3 - 3 } Decorative Method & No. & Percentage \\
${ } }$ & & \\
Brushed & 34 & 51.5 \\
Brushed-Incised & 1 & 1.5 \\
lncised & 7 & 21.2 \\
Punctated & 7 & 10.6 \\
lncised-Punctated & & 10.6 \\
Fine Wares & 3 & \\
Engraved & 66 & 4.5 \\
\hline Totals & & 100.0 \\
\hline
\end{tabular}

There are also two Woodland period decorated sherds in the Three Mounds Creek collection. The first is a rocker stamped sherd, with rows of rocker stamping; is not large enough to determine if the stamping is zoned by incised lines (cf. varieties of Marksville Stamped, including var. Trovville) or not (cf. Indian Bay Stamped, Tchefuncte Stamped, or Chevalier Stamped) (see Brown 1998:33-34). The second sherd is a 
grog-tempered body sherd with parallel rows of dentate stamps, likely an unidentified variety of Marksville Stamped. The rocker stamped sherd and the dentate stamped sherd point to a pre-A.D. 850 Woodland period use of the Three Mounds Creek site, as do the Woodland period Gary dart points in the collection.

\section{Lithic Artifacts}

Lithic artifacts from the ancestral Caddo occupation of the site include a triangular-shaped arrow point preform of yellowish-brown chert and an unidentilied stemmed arrow point fragment of a local quartzite. There are also 10 miscellaneous Late Archaic and Woodland style dart points in the collection.

\section{SUMMARY AND CONCLUSIONS}

The main component at the Three Mounds Creek site likely dates from the late $13^{\text {th }}$ century to the mid$15^{\text {th }}$ century A.D. This is based on the relative proportions of brushed sherds in the overall decorated sherd assemblage and the two engraved bottle sherds with pendant triangles. Because brushed vessels continued to be made by Caddo groups living in the Sabine River basin into the $17^{\text {th }}$ century, it may well have been occupied that late. Most likely, however, given the ages of the many other known sites in this part of the Sabine River basin, it seems probable that the Three Mounds Creek site was occupied at the same time (ca. A.D. 1300 to at least the mid-A.D. 1500s) as the premier Caddo mound center in this part of the Sabine River basin-the Pine Tree Mound site (41HS15, Fields and Gadus 2012). It may have been a subsidiary mound in a larger political community in this locale.

\section{ACKNOWLEDGMENTS}

Thanks to Patti Haskins of the Gregg County Historical Museum for making these artifacts from the Three Mounds Creek site available for study.

\section{REFERENCES CITED}

Brown, I. W.

1998 Decorated Pottery of the Lower Mississippi Valley: A Sorting Manual. Mississippi Archaeological Association and Mississippi Department of Archives and History, Jackson.

Fields, R. C. and E. F. Gadus

2012 Archeology of the Nadaco Caddo: The View from the Pine Tree Mound Site (4IHS15), Harrison County, Texas. Reports of Investigations No. 164. Prewitt and Associates, Inc., Austin.

Hart, J. P. and T. K. Perttula

2010 The Washington Square Mound Site and a Southeastern Ceremonial Complex Style Zone among the Caddo of Northeastern Texas. Midcontinental Journal of Archaeology 35(2): 199-228.

Perttula, T. K.

2012 Three Mounds Creek Site, Gregg County, Texas. Journal of Northeast Texas Archaeology 36:33-36. 